\title{
_Recent Publications
}

M. Hasegawa et al.: Rare-earth magnets for applications over a wide temperature range. J. Magn. Magn. Mater. 124 (1993), 325

L. Dascalescu et al.: Corona and electrostatic electrodes for high-tension separators. J. Electrostatics 29 (1993), 211

L. Dascalescu et al.: Numerical analysis of the electric field of roll-type electrostatic separators. J. Electrostatics 29 (1993), 255

D.O. Gothard et al.: Effectiveness of magnetic separation on the properties of powder metallurgy based aluminium-alloys. Proc. Conf. Advances in Powder Metallurgy and Particulate Materials, San Francisco 1992

Y. Lin et al.: Using rare-earth permanent magnetic material for developing medium-intensity magnetic separator. Proc. Conf. 2nd Internatl. Symp. on Physics of Magn. Mater., Beijing, China 1992

Z. Hiroi et al.: A new family of copper oxide superconductors $\mathrm{Sr}_{\mathrm{n}+1} \mathrm{Cu}_{\mathrm{n}} \mathrm{O}_{2 \mathrm{n}+1+} \delta$ stabilized at high pressure. Nature 364 (1993), 315

M.B. Bush: The stagnation flow behind a sphere. J. Non-Newton. Fluid Mech. $49(1993), 103$ (1993), 42

Th. C. Halsey and J.E. Martin: Electrorheological fluids. Sci. Amer. 269/4

A. Edgar and J.W. Quilby: A mutual inductance apparatus for measuring magnetic susceptibility and electrical conductivity. Amer. J. Phys. 61 (1993), 943

G.G. Ross: A 'Theory of Everything'. Contemp. Phys. 34 (1993), 79

Y. Ren et al.: Quasi permanent superconducting magnet of very high field. $J$. Appl. Phys. 74 (1993), 718

H. Inoue et al.: Interaction energy between magnetic particles in a disperse system. J. Magn. Magn. Mater. 124 (1993), 213

K.R. Brownstein: Force exerted on a magnetic dipole. Amer. J. Phys. 61 (1993), 940

M.A. Youssef et al.: A new technique for the magnetic concentration of manganiferous iron ores by sintering (in German). Neue Hutte 37 (1992), 88

C.W. Chu et al.: Superconductivity above $150 \mathrm{~K}$ in $\mathrm{HgBa}_{2} \mathrm{Ca}_{2} \mathrm{Cu}_{3} \mathrm{O}_{8+} \delta$ at high pressures. Nature 365 (1993), 323 
Y. Wang and E. Forssberg: Hydrophobic magnetite seeding of hematite in HGMS. Miner. Eng. 6 (1993), 537

J.M. Broto et al.: Magnetic properties of nanometric nickel particles. Solid State Commun. 85 (1993), 263

R. Coehoorn: Permanent magnets. A book chapter in Electron Theory in Alloy Design (The Institute of Materials, London, UK), 1992, pages 234-263

K. Yamanaka et al.: Magnetic viscosity of oriented barium ferrite media. J. Magn. Magn. Mater. 127 (1993), 233

N. Videnov et al.: Beneficiation of diatomites by HGMS. Intl. J. Miner. Proc. 39 (1993), 291

J. Segovia and G. Schena: Assessing profitability of mineral processing. Miner. Eng. 6 (1993), 1203

C.K. Gupta et al.: Extractive metallurgy of rare earths. Intl. Materials Reviews 37 (1992), 197

R.s. Mactaggart et al.: A conducting probe for measuring local solids concentration in a slurry mixing tank. Separ. Technol. 3 (1993), 151

S. Labroo et al.: Mechanism of magnetic separation of fine $\mathrm{Y}-\mathrm{Ba}-\mathrm{Cu}-\mathrm{O}$ powders in a fluidized bed. Cryogenics 39 (1993), 1063

A. Elby: What makes a theory physically complete? Foundations of Physics 23 (1993), 971

K.P. Belov: Electronic processes in magnetite ("Magnetite mysteries"). Usp. Fiz. Nauk. 163 (1993), 56 (in Russian)

S. Odenbach: Magnetic fluids. Adv. Colloid. Interface Sci. 46 (1993), 263

B. A. Kapitonov: Sputtered permanent NdFeB magnets. J. Magn. Magn. Mater. 127 (1993), 289

C.S. Grant: Electrokinetic separation of ultrafine materials. A review. Separ. Purif. Methods 22 (1993), 55

Y.M. Wang: Some practical problems on application of HGMS. Mining and Metallurgical Engineering (China) 13 (1993), 21 (in Chinese)

D. Horvath and P. Kopcansky: Magnetic dimer motion effects in a rotating magnetic field (a qualitative model of magnetoviscosity and permittivity in magneto-rheological suspensions). Czech. J. Phys. 43 (1993), 671

O. Okai et al.: Response of a living body to 8 Tesla magnetic field. Sci. Rep. Res. Inst. Tohoku University A38 (1993), 406

Li Ming De et al.: Development of CRIMM roll-type high-intensity magnetic separators with rare earth permanent magnets. Min. Metall. Eng. (China) 13 (1993), 32 (in Chinese) 
Austpac ERMS ilmenite progress. Industr. Miner., September 1993, 13.

I. Klik and C.R. Chang: Duration of magnetic aftereffect. J. Magn. Magn. Mater. 128 (1993), L17

D. Ritson: Demise of the Texas supercollider. Nature 366 (1993), 607

D.H. Zhu and Z.X. Chen: Choosing the shapes of a steel housing for solenoid magnets. Min. Metall. Eng. (China) 12 (1992), 44 (in Chinese)

H. Tateishi: Stability of superconducting cables for use in large magnet systems. Bull. Electrotech. Lab. (Japan) 56 (1992), 30 (in English)

J.W. Lyman and G.R. Palmer: Recycling of neodymium iron boron magnet scrap. US Bureau of Mines Report RI 9481 (1993), 28 pp.

R. Beckmann et al.: Assessment of processes for municipal residual waste separation. Aufbereitungstechnik 34 (1993), 296

T. Sakaguchi et al.: Magnetite formation by a sulphate-reducing bacterium. Nature 365 (1993), 47

Y. Kawate and R. Ogawa: Superconducting magnets and superconductors at Kobe Steel Ltd. Japan, 21st July 1993, 84

R.J. Cava et al.: Superconductivity at $23 \mathrm{~K}$ in yttrium palladium boride carbide. Nature 367 (1994), 146

L.R. Avens et al.: Magnetic separation for soil decontamination. Proc. Symposium on Waste Management, Tucson, Arizona, USA (1993), 787

H.E. Plumblee, Jr. et al.: Development of an actinide magnetic separation system for enhancement of the TRUclean system. Proc. Symposium on Waste Management, Tucson, Arizona, USA (1993), 791 